\title{
ANALYSIS OF CHARACTERISTICS IN CHINA CLASSIC DANCERS' GAIT PATTERN
}

\author{
Yihong ZHAO ${ }^{1,2}$, Ziyu LIU ${ }^{1}$, Xuelian ZHANG ${ }^{3}$, Luming YANG ${ }^{1,2^{*}}$, Wuyong CHEN $^{1}$ \\ ${ }^{1}$ National Engineering Laboratory for Clean Technology of Leather Manufacture, Chengdu, 610065, China \\ ${ }^{2}$ Key Laboratory of Leather Chemistry and Engineering (Sichuan University), Chengdu, 610065, China \\ ${ }^{3}$ Sichuan Vocational College of Art, Chengdu 610065,China
}

Received: 07.02.2018

Accepted: 31.05 .2018

https://doi.org/10.24264/Ifj.18.2.8

\section{ANALYSIS OF CHARACTERISTICS IN CHINA CLASSIC DANCERS' GAIT PATTERN}

ABSTRACT. China Classic Dance is one of the most important and popular dancing in China and has become more and more popular from all over the world. However, the special gait patterns for the China Classic Dancers are not clear. The purpose of this study was to compare the characteristics of plantar pressure distribution in the China Classic Dancers and the non-dancers, and recognize if force transference happened. Gait data (PP, Fmax, PTI, FTI and FTIrel) from 93 China Classic Dancers and 30 non-dancers were analyzed. The plantar force transference was accessed with a load-transfer algorithm. Significant differences were found in plantar pressure distribution between the two groups: 1. maximum forces for China Classic Dancers significantly lower than the control group except the T1 and M2 regions; 2 . peak pressures showed significant decrease in the China Classic Dancers except the M2 region; 3 . the force-time integrals and pressure-time integrals in each region reduced significantly in comparison with the controls; 4. main significant load transferences were observed from T1, lateral forefoot (M3-5), midfoot and HM regions to the medial forefoot (M1-2) areas (T1, M3-5, MF, HM $\rightarrow$ M1-2). And the medial to lateral transferences were typical in toes and heel regions ( $\mathrm{T} 1 \rightarrow \mathrm{T} 2-5, \mathrm{HM} \rightarrow \mathrm{HL}$ ). These results suggested a typical gait patterns for the China Classic Dancers. Further investigation is needed in sports biomechanics and injuries for this special population.

KEY WORDS: China Classic Dance, plantar pressure, load transference

\section{ANALIZA CARACTERISTICILOR TIPARULUI DE MERS AL DANSATORILOR DE DANS CLASIC CHINEZESC}

REZUMAT. Dansul clasic chinezesc este unul dintre cele mai importante și populare dansuri din China și a devenit unul dintre cele mai populare din întreaga lume. Cu toate acestea, tiparele de mers specifice dansatorilor de dans clasic chinezesc nu sunt clare. Scopul acestui studiu a fost de a compara caracteristicile distribuției presiunii plantare ale dansatorilor de dans clasic chinezesc și ale non-dansatorilor și de a determina dacă a avut loc transferul de forță. S-au analizat date privind mersul (PP, Fmax, PTI, FTI și FTIrel) preluate de la 93 de dansatori de dans clasic chinezesc și 30 de non-dansatori. Transferul forței plantare a fost măsurat cu un algoritm de transfer de greutate. S-au constatat diferențe semnificative în distribuția presiunii plantare între cele două grupuri: 1 . forțele maxime la dansatorii de dans clasic chinezesc au fost semnificativ mai mici decât în cazul grupului martor, cu excepția regiunilor T1 și M2; 2. presiunile maxime au prezentat o scădere semnificativă în cazul dansatorilor, cu excepția regiunii M2; 3. integralele forță-timp și presiune-timp au scăzut semnificativ în fiecare regiune în comparație cu grupul martor; 4. principalele transferuri semnificative de greutate au fost observate din zona T1, zona antepiciorului lateral (M3-5), zona mediană și HM către antepiciorul median (M1-2) (T1, M3-5, MF, HM $\rightarrow$ M1-2). Transferurile din zona mediană spre cea laterală au fost observate în regiunile degetelor și călcâiului (T1 $\rightarrow \mathrm{T} 2-5, \mathrm{HM} \rightarrow \mathrm{HL}$ ). Aceste rezultate au sugerat un tipar de mers specific dansatorilor de dans clasic chinezesc. Sunt necesare investigații suplimentare în domeniul biomecanicii sportive și al leziunilor specifice acestei populații.

CUVINTE CHEIE: dans clasic chinezesc, presiune plantară, transfer de greutate

\section{L'ANALYSE DES CARACTÉRISTIQUES DU MODÈLE DE LA MARCHE CHEZ LES DANSEURS CLASSIQUES DE CHINE}

RÉSUMÉ. La danse classique chinoise est l'une des danses les plus importantes et les plus populaires de la Chine qui est devenue l'une des danses de plus en plus populaire dans le monde entier. Cependant, les modèles des danseurs classiques chinois ne sont pas clairs. Le but de cette étude a été de comparer les caractéristiques de distribution de la pression plantaire chez les danseurs classiques et les non-danseurs et de déterminer s'il y avait transfert de la force. On a analysé les données de marche (PP, Fmax, PTI, FTI et FTIrel) prises à partir de 93 danseurs classiques et 30 non-danseurs. Le transfert de la force plantaire a été mesuré avec un algorithme de transfert de poids. Il y avait des différences significatives dans la répartition de la pression plantaire entre les deux groupes: 1 . les forces maximales aux danseurs de la danse classique chinoise ont été significativement plus faibles que dans le cas du groupe témoin, sauf pour les régions T1 et M2; 2 . les pressions maximales ont montré une diminution significative pour les danseurs, à l'exception de la région $\mathrm{M} 2 ; 3$. les intégrales force-temps et pressiontemps sont diminuées de manière significative dans chaque région par rapport au groupe de contrôle; 4 . les principaux transferts de poids importants ont été observés de la région $\mathrm{T} 1$, la région latérale de l'avant-pied (M3-5), la région médiane et la région $\mathrm{HM}$ à la région médiane de l'avant-pied (M1-2) (T1, M3-5, MF, HM $\rightarrow$ M1-2). Les transferts de la région médiane vers les régions latérales ont été observés dans les doigts et le talon ( $\mathrm{T} 1 \rightarrow \mathrm{T} 2-5, \mathrm{HM} \rightarrow \mathrm{HL}$ ). Ces résultats suggèrent un modèle de marche spécifique aux danseurs de danse classique chinois. Des investigations complémentaires sont nécessaires dans le domaine de la biomécanique sportive et des lésions spécifiques de cette population. MOTS CLÉS: danse classique chinoise, pression plantaire, transfert de poids

\footnotetext{
* Correspondence to: Luming YANG, National Engineering Laboratory for Clean Technology of Leather Manufacture, Chengdu, 610065, China, Tel.: +861862811 7800, email: ylmll1982@126.com
} 


\section{INTRODUCTION}

China Classic Dance began in 1950s, as a branch of the Chinese dancing art. It was a typical dance with classical styles created and evolved from Chinese national and folk dances, which combines dance, Chinese traditional opera, folk acrobatics and Chinese martial art etc. [1-3]. This style of dance is well known for dancers' body tenacity and 'hardness with softness'. There are three principles about movements and rhythm in China Classic Dance: circling with the body, rotating with the waist and reverse force, which are typically different from other dances like ballet or Latin [4]. More and more people especially children begin to learn China Classic Dance due to its aesthetic and gymnastic character.

Dancers, after long-term dancing trainings, get a stronger cardiovascular and respiratory system. Main techniques in Chinese Classic Dance have a strong impact on dancers' posture, muscle strength and ligament strength [5]. Notably, the dancers' forefeet tend to be stronger to grasp the ground more easily and dancers' flexibility and balance also get improved after training.

Overloaded structures of foot due to extreme body position would affect the higher body segments in return, which may contribute to arch collapse, joint sprain, hip and back pain, muscle strain, cervical spine injury and anterior knee pain. T.O. Smith et al. [6] did a survey to evaluate musculoskeletal health in retired professional ballet dancers in the United Kingdom, and found thirty-six percent of the respondents reported retiring from ballet dancers due to musculoskeletal injury and the common issues were hip and back pain (25\%), hamstring injuries, ankle injuries, cervical spine injuries, and anterior knee pain $(13 \%$ respectively). Megan Noon et al. [7] found that the top injuries of the Irish dancers included stress fractures $(29.9 \%)$, patellofemoral pain syndrome (11.1\%), sever condition $(6.0 \%)$, ankle sprains $(5.1 \%)$, posterior tibialis $(4.6 \%)$, and plantar fasciitis (4.6\%). And the majority of injuries were in the lower extremities (94.9\%). It has been proved that ballet dancers had a special gait pattern compared with the non-dancers [8]. However, the previous study about dancers' plantar pressure and other musculoskeletal system parameters mainly focused on ballet and Latin or other dance types, rarely on Chinese Classic Dance [9-15]. It is an important issue for China Classic Dancers, trainers and learners to know the typical gait patterns and the relevant prevention. In this study, China Classic Dancers' plantar pressure patterns were measured and analyzed to fill the research blank in this field. The results will provide references for prevention and treatment of motor injury and foot disease.

\section{METHODS AND MATERIAL}

\section{Participants}

Ninety-three China Classic Dancers with no history of lower extremity injury in the past six months and no foot deformity were recruited in this study. Thirty healthy non-dancers within comparable criteria (age, height, weight, shoe size, dancing experience) were involved as the control group. Basic information of the subjects was shown in Table 1. Written informed consent was received from all participants prior to the test in accordance with the Declaration of Helsinki. The study was approved by the Ethics Committee of Sichuan University.

Table 1: Basic information of the participants

\begin{tabular}{ccccccc}
\hline Groups & $\mathrm{n}$ & $\begin{array}{c}\text { Age } \\
\text { (year) }\end{array}$ & $\begin{array}{c}\text { Height } \\
(\mathrm{cm})\end{array}$ & $\begin{array}{c}\text { Weight } \\
(\mathrm{kg})\end{array}$ & $\begin{array}{c}\text { Shoe size } \\
(\mathrm{mm})\end{array}$ & $\begin{array}{c}\text { Dancing experience } \\
\text { (year) }\end{array}$ \\
\hline $\begin{array}{c}\text { Dancers } \\
\text { Non-dancers }\end{array}$ & 93 & $19 \pm 1$ & $160.0 \pm 2.2$ & $49.1 \pm 4.1$ & $230 \pm 10$ & $11 \pm 3$ \\
\end{tabular}

\section{Apparatus}

Plantar pressure data were collected using a Footscan ${ }^{\circledR}$ plate system (RSscan Inc., Belgium;
Figure 1) with a sampling rate of $250 \mathrm{~Hz}$. The $1-\mathrm{m}$ plantar pressure plate has 8192 force sensors, and its weight, dimensions and resolution are: 
$7.7 \mathrm{~kg}, 1068 \mathrm{~mm} \times 418 \mathrm{~mm} \times 12 \mathrm{~mm}, 7.62 \mathrm{~mm} \times$ $5.08 \mathrm{~mm}$, and $500 \mathrm{~Hz}$, respectively. The plate can stand $200 \mathrm{~N} / \mathrm{cm}^{2}$ at most.

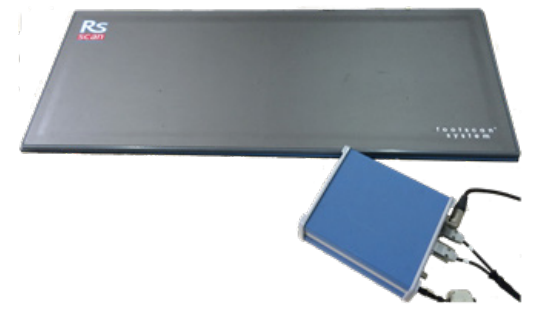

Figure 1. Footscan ${ }^{\circledR}$ plate system

\section{Procedure}

The test was conducted in an indoor laboratory. The plantar pressure plate was installed in the middle of a 6-m rigid rubber track of same height, to estimate a natural walking condition. Prior to data collection there was a familiarization period to reduce targeting, determine a start position and ensure several steps were taken before walking over the plate. Subsequently, participants walked through the plates barefoot at a self-selected speed, using a "two-step" method, which confirmed two complete footprints on the plate (Figure 2). Five successful footprints of each foot were measured for data analysis.

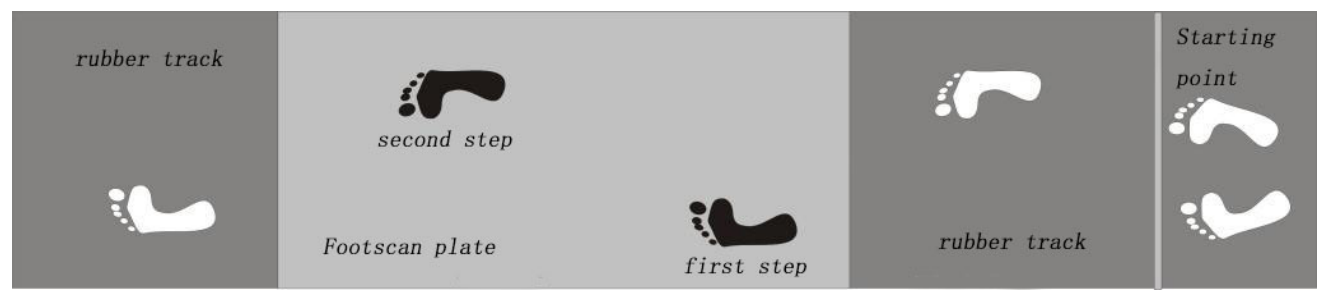

Figure 2. 'Two-step' method

\section{Data Analysis and Reduction}

The plantar surface was divided into ten regions (Figure 3 ) by Footscan software and artificial adjustment according to the anatomical principal and test requirements: Toe 1 (T1), Toes 2-5 (T2-5), the first to fifth metatarsal (M1, M2, M3, M4, M5), Midfoot (MF), Heel medial (HM), Heel lateral $(\mathrm{HL})$. The plantar pressure data of the subjects' preferred foot (right foot) were analyzed only, since the China Classic Dancers rely more on their preferred foot during training. Plantar pressure variables involved in this study included: peak pressure ( $\mathrm{kPa} ; \mathrm{PP})$, maximum force (N; Fmax); the pressure-time integral (PTI); the force-time integral (FTI). Data from three relative stable measurements of each subject were averaged to minimize artificial accidental error and make the results more authentic.

Normality of the data was assessed using Kolmogorov-Smirnov test $(p>0.05)$, and the differences between two groups were tested by Independent Samples T Test $(p<0.05)$.
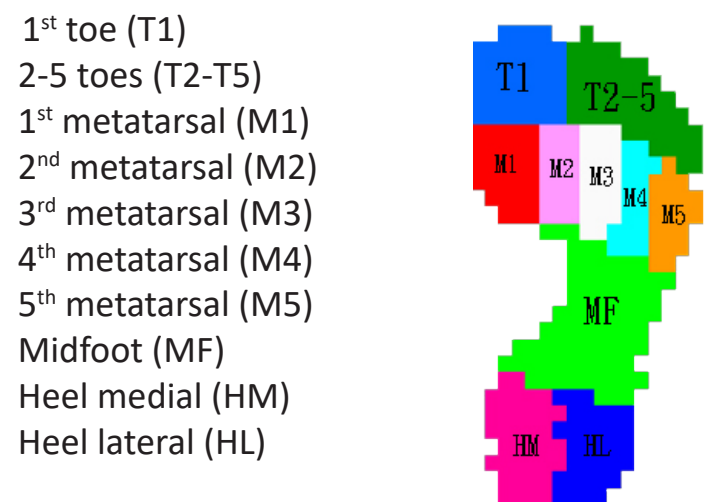

Figure 3. Regions of plantar surface 


\section{Load Transfer Algorithm}

The FTI is a measure of force impulse or the load applied to the plantar region. The total impulse on the foot for the two groups may change if the gait patterns of the two groups are different. Thus, the relative FTI values (FTIrel) were required in this study. Then, the FTIrel difference in each plantar region of the two groups was calculated by the FTIrel mean of the dancer-group minus that of control-group for each area (Figure 2.a). A negative result would suggest that the relative load of the dancergroup was lower than that of the controls; vice versa for a positive outcome.

The posterior-anterior and lateral-medial force transferences happen along the foot arch. In which direction or order does the load transfer is still not clear, but it does not matter with the final transferring trend. Thus, a load transfer algorithm similar to that of a previous study was adopted in this work [16]. Details of the algorithm were presented as below:

Rule 1. The foot plantar is divided into four levels, based on the former regional partitions: the toe regions for Level 1 , the forefoot region for Level 2, the midfoot region for Level 3 and the heel for Level 4.

Rule 2. The regional differences for the two groups are presented in each region. The load transfer from the area with a positive difference to the area with a negative outcome until a 0 is reached in one area, which would not participate in the transference any more.

Rule 3. The inter-level transferences happen first. And the force transfer between the neighbor regions prior to the others.

Rule 4. The intra-level transferences happen next. And the load transfer between the adjacent levels in preference to others.

\section{RESULTS}

\section{Characteristics of Maximum Force}

The results of maximum force were illustrated in Table 2. Heel, M1 and M2 regions were the main supporting and bearing areas, in which the maximum force was the largest. Significant differences were observed in all regions between the two groups except the M1 region. The maximum force value in the T1 region of the China Classic Dancers $(p<0.001)$ was significantly higher than that of the nondancers. However, the results of other regions (T2-5: $p=0.008 ; \mathrm{M} 2: \mathrm{p}=0.021 ; \mathrm{M} 3: \mathrm{p}<0.001$; M4: $p<0.001$; M5: $p=0.001$; MF: $p<0.001$; HM: $p<0.001 ; H L: p=0.001)$ were lower compared with the control groups.

Table 2: Comparison of maximum force $(\mathrm{N})$ between the two groups

\begin{tabular}{ccc}
\hline & China Classic Dancers & Control group \\
\hline T1 & $70.37 \pm 42.99^{*}$ & $30.00 \pm 20.98$ \\
T2-5 & $22.05 \pm 21.44^{*}$ & $34.80 \pm 21.45$ \\
M1 & $128.69 \pm 65.94$ & $91.12 \pm 38.60$ \\
M2 & $108.24 \pm 55.01^{*}$ & $147.41 \pm 46.57$ \\
M3 & $72.00 \pm 42.68^{*}$ & $137.10 \pm 50.39$ \\
M4 & $48.73 \pm 35.14^{*}$ & $77.23 \pm 31.94$ \\
M5 & $24.93 \pm 19.11^{*}$ & $46.40 \pm 23.95$ \\
MF & $58.60 \pm 45.41^{*}$ & $111.02 \pm 47.88$ \\
HM & $125.48 \pm 56.89^{*}$ & $183.05 \pm 52.39$ \\
HL & $114.12 \pm 52.55^{*}$ & $143.46 \pm 43.88$ \\
\hline
\end{tabular}

${ }^{*}$ represents $\mathrm{p}<0.05$

\section{Characteristics of Peak Pressure}

The plantar peak pressure of China Classic Dancers were significantly lower in T1, T2-5, M1, M3, M4, M5, Midfoot, HM and HL regions than the controls $(p<0.05)$. The peak pressure in $M 2$ region $(p=0.222)$ showed no significant difference (Table 3 ).

Table 3: Comparison of peak pressure $\left(\mathrm{N} / \mathrm{cm}^{2}\right)$ between the two groups

\begin{tabular}{ccc}
\hline & China Classic Dancers & Non-dancers \\
\hline T1 & $4.70 \pm 4.51^{*}$ & $6.88 \pm 2.53$ \\
T2-5 & $1.27 \pm 1.35^{*}$ & $1.69 \pm 0.72$ \\
M1 & $5.29 \pm 4.11^{*}$ & $7.00 \pm 2.46$ \\
M2 & $11.36 \pm 10.02$ & $14.35 \pm 2.79$ \\
M3 & $8.99 \pm 8.19^{*}$ & $16.55 \pm 4.74$ \\
M4 & $6.20 \pm 6.19^{*}$ & $9.65 \pm 3.76$ \\
M5 & $3.23 \pm 3.55^{*}$ & $4.47 \pm 2.32$ \\
MF & $1.65 \pm 2.06^{*}$ & $2.86 \pm 0.86$ \\
HM & $6.41 \pm 5.26^{*}$ & $12.17 \pm 2.25$ \\
HL & $6.75 \pm 5.41^{*}$ & $11.08 \pm 2.99$ \\
\hline
\end{tabular}

${ }^{*}$ represents $\mathrm{p}<0.05$

\section{Characteristics of the Force-time Integral}

The results in Table 4 suggested that the FTI values of the China Classic Dancers were significantly lower than those of the non-dancers in all plantar regions except for M1. This was in 
consistent with the result of the maximum force characteristics.

Table 4: Comparison of force-time integral (N.s) between the two groups

\begin{tabular}{ccc}
\hline & China Classic Dancers & Non-dancers \\
\hline T1 & $12.21 \pm 9.55^{*}$ & $26.33 \pm 10.88$ \\
T2-5 & $4.51 \pm 6.72^{*}$ & $7.80 \pm 6.28$ \\
M1 & $24.56 \pm 16.53$ & $26.54 \pm 16.18$ \\
M2 & $31.05 \pm 19.74^{*}$ & $46.35 \pm 28.14$ \\
M3 & $19.96 \pm 14.43^{*}$ & $44.55 \pm 27.66$ \\
M4 & $12.79 \pm 10.66^{*}$ & $26.59 \pm 14.39$ \\
M5 & $7.58 \pm 8.43^{*}$ & $16.11 \pm 15.73$ \\
MF & $14.70 \pm 13.54^{*}$ & $33.25 \pm 17.63$ \\
HM & $25.36 \pm 13.99^{*}$ & $52.99 \pm 38.09$ \\
HL & $23.66 \pm 15.30^{*}$ & $39.62 \pm 28.91$ \\
\hline
\end{tabular}

${ }^{*}$ represents $p<0.05$

\section{Characteristics of Pressure-time Integral}

Significant differences were found in PTI values between two groups in all plantar regions $(p<0.05)$ except for $M 2 \quad(p=0.123)$, which was similar to the result of peak pressure characteristics. China Classic Dancers' PTI values reduced significantly in $\mathrm{T} 1(\mathrm{p}<0,001), \mathrm{M} 3$ $(p<0,001), M 4(p=0,004), M 5(p=0,005)$, Midfoot $(p<0,001), H M(p<0,001)$ and $H L(p<0,001)$; and mildly reduced in $\mathrm{T} 2-5(\mathrm{p}=0.037)$ and $\mathrm{M} 1$ $(p=0.046)$ regions (Table 5$)$.
Table 5: Comparison of pressure-time integral $\left(\mathrm{N} / \mathrm{cm}^{2} \cdot \mathrm{s}\right)$ between the two groups

\begin{tabular}{ccc}
\hline & China Classic Dancers & Non-dancers \\
\hline T1 & $0.96 \pm 0.59^{*}$ & $1.25 \pm 0.55$ \\
T2-5 & $0.24 \pm 0.27^{*}$ & $0.28 \pm 0.15$ \\
M1 & $1.49 \pm 0.79^{*}$ & $1.68 \pm 0.77$ \\
M2 & $3.24 \pm 1.88$ & $3.64 \pm 0.81$ \\
M3 & $2.78 \pm 1.71^{*}$ & $4.31 \pm 1.10$ \\
M4 & $2.00 \pm 1.41^{*}$ & $2.72 \pm 0.90$ \\
M5 & $0.82 \pm 0.71^{*}$ & $1.22 \pm 0.62$ \\
MF & $0.41 \pm 0.32^{*}$ & $0.72 \pm 0.22$ \\
HM & $1.73 \pm 0.89^{*}$ & $2.70 \pm 0.69$ \\
HL & $1.78 \pm 0.92^{*}$ & $2.40 \pm 0.55$ \\
\hline
\end{tabular}

"represents $p<0.05$

\section{Characteristics of Load Transference Mechanism}

The FTIrel values and the FTIrel differences of the two groups were presented in Table 6. It suggested obvious load transference in Figure 4. The Heel and M1-2 regions were the main loading areas during the dancers' walking. The increase of FTIrel in M1-2 regions resulted from lateral forefoot, $\mathrm{T} 1$ and the HM areas. Furthermore, lateral to medial force transferences happened both in the toe and heel areas, which contributed a better load balance in the heel area.

Table 6: Comparison of the FTIrel (\%) values between the two groups

\begin{tabular}{cccc}
\hline & China Classic Dancers & Non-dancers & Differences (\%) \\
\hline T1 & 6.92 & 8.22 & 1.3 \\
T2-5 & 2.56 & 2.44 & -0.1 \\
M1 & 13.92 & 8.29 & -5.6 \\
M2 & 17.60 & 14.48 & -3.2 \\
M3 & 11.32 & 13.92 & 2.6 \\
M4 & 7.25 & 8.31 & 1.1 \\
M5 & 4.30 & 5.03 & 0.7 \\
MF & 8.33 & 10.39 & 2.1 \\
HM & 14.38 & 16.55 & 2.2 \\
HL & 13.41 & 12.38 & -1.1 \\
\hline
\end{tabular}




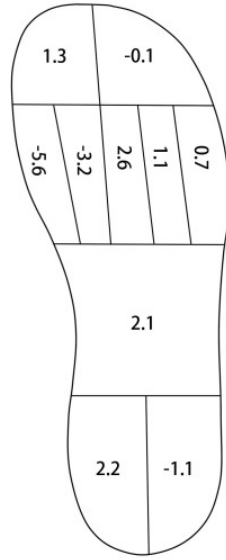

(a)

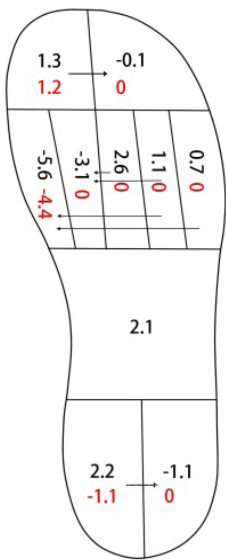

(b)

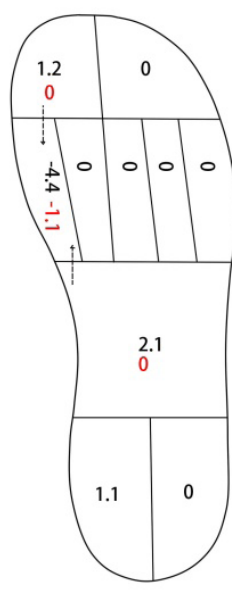

(c)

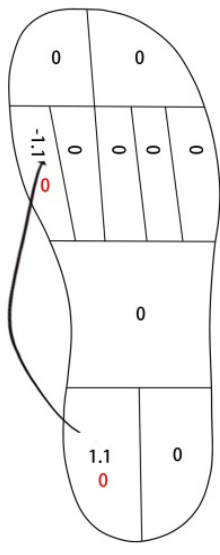

(d)

Figure 4. The load transference of the dancers compared with controls. (a) Regional differences in FTIrel between two groups; (b) Inter-level load transferences; (c) Intra-level adjacent force transferences; (d) Across level load transference. Figures in red color represented the rest of the FTIrel values after transferences.

\section{DISCUSSION}

The characteristics of the plantar pressure distribution were first investigated for China Classic Dancers during their normal walking in this study. In general, the results showed that the China Classic Dancers were significantly different from the non-dancers in all variables analyzed. And interestingly, significantly lower plantar pressure distributions were found in most plantar regions for the dancers. Special habitual toe-heel walking altered the ballet dancers' gait patterns even during daily normal walking [8]. China Classic Dancers need to practice to keep body tenacity and softness and it is important to involve muscle activation and ligament in some postures in their long-term dancing career. So, their movement e.g. walking would be milder and lighter than other people's. On the other hand, accumulating exercises may change their foot shape or even the musculoskeletal structures and kinematics characteristics of their lower extremities. Nili Steinberg et al. [17] found that 307 of the 1288 dancers were diagnosed as having scoliosis, and the scoliotic dancers presented a significantly higher prevalence of anatomical anomalies such as hallux valgus.

Significant differences have been found in the average EMG of tibialis anterior when Latin dancers danced wearing different heel height shoes [18]. Jeffrey et al. [14] noted incongruence of the talocrural joint and convergence of the tibia, talus, and calcaneus posteriorly. All these adaptations and changes were due to special dance-required postures and trainings. To achieve the extreme positions requested in the Chinese Classic Dance, dancers' musculoskeletal system may be adjusted to make some compensation like the foot pronation and toe-out gait of the ballet dancers. And this compensation mechanism plus long-term and intensive dancing training may change the dancers' gait stereotypes, such as the plantar pressure distribution.

Significantly lower peak pressure in all regions except M1 were found in China Classic Dancers. However, previous study found that there was a significant reduction of peak pressure in T2-5, M5 and MF regions and a significant increase in $\mathrm{T} 1, \mathrm{M} 1$ and $\mathrm{M} 2$ plantar regions in ballet dancers than in non-dancers. Especially in the $\mathrm{T} 1$ and $\mathrm{M} 2$ regions, the findings of the two studies were totally opposite. Furthermore, the pressure impulse in the China Classic Dancers tended to be more medial and the load in the subjects' heel was lower than that in the ballet dancers [8]. The disagreement might result from different calculating methods of peak pressure and different dancing types, as Chinese Classic Dance and ballet have different typical positions [19]. 
It was interesting to note that $\mathrm{T} 1$ region of the China Classic Dancers loaded significantly a higher maximum force but a lower peak pressure, which might be due to a larger contact area or a bigger and stronger hallux. The FTI and PTI of the hallux area were significantly lower in the China Classic Dancers, so the big toe was not the main loading area. The medial forefoot was found to have an obviously higher loading rate than that of the non-dancers, regarding the results of the FTI and the PTI.

The load transferences happened in China Classic Dancers compared with the controls were also investigated. Clear force transference was observed, confirming that the medial forefoot and the heel areas loaded the most impact during the dancers' walking, which would probably lead to damage in the areas. And the transferring trend to the medial forefoot may account for the great importance and function of the areas for the dancers. Another kind of interesting shifting was found in the toe and heel areas, medial to lateral transference, which resulted in a better load balance.

In this study, we focused only on the PP, Fmax, FTI and PTI parameters and the load transference of the dancers. So it is necessary to do more research about the lower extremity typical condition of China Classic Dancers such as the foot shape, surface EMG, kinematic features and kinetic characteristics etc. to strengthen the whole study system.

\section{CONCLUSION}

To our knowledge, this is the first study to investigate the characteristics of plantar pressure distribution of the China classic dancers during walking. The results did show many significant differences between the dancers and non-dancers. The four gait parameters and the load transference both suggested the typical characteristics of China Classic dancers' plantar pressure during natural walking is that relying more on the medial forefoot. So, it was necessary to take some targeted health promotion intervention for dancers' feet to prevent more foot diseases and sports injury such as designing special shoes for these China Classic Dancers in daily walking. Furthermore, it could be deduced from the different gait patterns between ballet dancers and China Classic Dancers that different dance types may affect the characteristics of the dancers' motor behaviors differently. This was also the basis of the rehabilitation of the different types of dancers' lower limbs.

\section{Acknowledgments}

The present study obtained financial support from National Natural Science Foundation of China, grant number: 11502154. The authors would like to acknowledge all the experimenters for subject recruitment and data collection, and to acknowledge all the participants who made this study possible. No writing assistance we had in this paper.

\section{REFERENCES}

1. Lv, Y.S., Introduction to Choreography (in Chinese), Shanghai Music Publishing House, 2009, 34-35.

2. Gui, Y., Zhao, D.D., Dance Appreciation and Creation (in Chinese), Zhejiang University Press, 2006, 57.

3. Zhang, L.L., On Chinese Dance, Youth Times, 2017, 4, 10.

4. Wang, Y.P., A General Discussion on Dance Art (in Chinese), Nanjing University Press, 2006, 32-35.

5. Lung, C.W., Chern, J.S., Yang, L.F., Hsiehand, S. et al., The Differences in Gait Pattern between Dancers and Non-Dancers, Journal of Mechanics, 2008, 24, 4, 451-457, https:// doi.org/10.1017/S1727719100002562.

6. Smith, T.O., de Medici, A., Oduoza, U. et al., National survey to evaluate musuloskeletal health in retired professional ballet dancers in the United Kingdom, Phys Ther Sport, 2017, 23, 82-85, https://doi.org/10.1016/j. ptsp.2016.07.009.

7. Noon, M., Hoch, A.Z., McNamara, L. et al., Injury Patterns in Female Irish Dancers, $P M R, 2010,2,11,1030-1034$, https://doi. org/10.1016/j.pmrj.2010.05.013.

8. Prochazkova, M., Tepla, L., Svoboda, Z. et al., Analysis of foot load during ballet dancers' gait, Acta Bioeng Biomech, 2014, 16, 2, 41-45. 
9. Rong, M., Li, J.S., Gu, Y.D., Research on the Plantar Pressure Distribution during Latin Dance, Zhejiang Sport Science, 2008, 30, 4, 113-115.

10. Jiang, L.Y., Li, W., Feng, N.N., Plantar pressure distribution for female college students majored in dance sport, Shandong Sports Science \& Technology, 2011, 03, 35-38.

11. Peng, X.Q., Pan, H.J., A Research on the Distribution Characteristics of Plantar Pressure in Different Kinds of Latin Dance (in Chinese), Journal of Beijing Sport University, 2011, 01, 67-69.

12. Steinberg, N., Waddington, G., Adams, R. et al., The effect of textured ballet shoe insoles on ankle proprioception in dancers, Phys Ther Sport, 2016, 17, 38, https://doi. org/10.1016/j.ptsp.2015.04.001.

13. Casabona, A., Leonardi, G., Aimola, E. et al., Specificity of foot configuration during bipedal stance in ballet dancers, Gait Posture, 2016, 46, 91, https://doi.org/10.1016/j. gaitpost.2016.02.019.

14. Russell, J.A., Yoshioka, H., Assessment of female ballet dancers' ankles in the en pointe position using high field strength magnetic resonance imaging, Acta Radiol, 2016, 57, 8, 978-984, https://doi. org/10.1177/0284185115616295.

15. Iunes, D.H., Elias, I.F., Carvalho, L.C. et al., Postural adjustments in young ballet dancers compared to age matched controls, Phys Ther Sport, 2015, 17, 51-57, https://doi. org/10.1016/j.ptsp.2015.04.004.
16. Hu, M., Zhou, N., Xu, B. et al., The mechanism of force transference in feet of children ages two to six, Gait Posture, 2017, 54, 15, https:// doi.org/10.1016/j.gaitpost.2017.02.019.

17. Steinberg, N., Hershkovitz, I., Peleg, S. et al., Morphological characteristics of the young scoliotic dancer, Phys Ther Sport, 2013, 14, 4, 213-220, https://doi.org/10.1016/j. ptsp.2012.07.003.

18. Li, J.S., Ruan, G.Q., Wang, Y.C. et al., Lower Limb Muscles SEMG Activity during HighHeeled Latin Dancing, Berlin, Heidelberg: Springer Berlin Heidelberg, 2010, 31, 198200.

19. Wu, Y., A Comparative Analysis of Basic Courses of Chinese Classic Dance and Ballet, Home Drama, 2016, 15, 158.

(C) 2018 by the author(s). Published by INCDTPICPI, Bucharest, RO. This is an open access article distributed under the terms and conditions of the Creative Commons Attribution license (http:// creativecommons.org/licenses/by/4.0/). 